\title{
Enriched eggs as a source of n-3 polyunsaturated fatty acids for humans
}

\author{
Gordana Kralik ${ }^{1}$, Zlata Kralik ${ }^{1}$, Eva Strakova² Manuela Grčević ${ }^{1}$, Danica Hanžek ${ }^{1}$ \\ ${ }^{1}$ Josip Juraj Strossmayer University of Osijek, Faculty of Agriculture in Osijek, \\ Department of Special Zootechniques, Osijek, Croatia \\ ${ }^{2}$ University of Veterinary and Pharmaceutical Science Brno, Faculty of Veterinary Hygiene and Ecology, \\ Department of Nutrition, Animal Husbandry and Animal Hygiene, Brno, Czech Republic
}

Received November 27, 2016

Accepted October 2, 2017

\begin{abstract}
The aim of the research was to enrich eggs with $n-3$ polyunsaturated fatty acids by using plant oils and fish oil as dietary supplements in laying hens' feed. The focus was put on the effect of the daily consumption of $100 \mathrm{~g}$ of egg yolk, i.e. $100 \mathrm{~g}$ of egg mass, on the human health. The $1^{\text {st }}$ group of laying hens was fed a diet containing soybean and fish oil, and the $2^{\text {nd }}$ group was given feed containing a combination of linseed, rapeseed, soybean, and fish oils. Eggs laid by the $2^{\text {nd }}$ group contained $4.73 \%$ $\alpha$-linolenic acid, $0.20 \%$ eicosapentaenoic acid and $2.37 \%$ docosahexaenoic acid $(\%$ of total fatty acids in yolk lipids, $P<0.001$ ), which marks an increase of $\times 4.04$ for $\alpha$-linolenic acid, $\times 3.33$ for eicosapentaenoic acid, and $\times 1.75$ for docosahexaenoic acid compared to eggs laid by the $1^{\text {st }}$ group. Total $n-3$ polyunsaturated fatty acids in eggs of the $2^{\text {nd }}$ group were $\times 2.8$ higher than in the $1^{\text {st }}$ first group. Calculated per $100 \mathrm{~g}$ of eggs of the $2^{\text {nd }}$ group, the intake for the human body corresponds to $435 \mathrm{mg} \alpha$-linolenic acid, $18.43 \mathrm{mg}$ eicosapentaenoic acid, and $218.2 \mathrm{mg}$ docosahexaenoic acid.
\end{abstract}

Deposition, ALA, EPA, DHA, consumption

Nutritionists recommend consumption of eggs enriched with n-3 polyunsaturated fatty acids (n-3 PUFA), having in mind the necessity of preventing various diseases and strengthening the immune system in humans. The benefit for human health is estimated on the basis of n-3 PUFA content in egg yolk lipids, as well as on the ratio of n- 6 / n-3 PUFA (Okuyama et al. 1997; Simopoulos 2000). Omega-3 fatty acids prevent the occurrence of rheumatoid arthritis and cancer (Aydin and Dogan 2010), as well as cardiovascular diseases (Van Elswik 1997; Raes et al. 2002; Pita et al. 2010), and have positive effects on the immune system (He et al. 2007). Rašić et al. (2014) determined that consumption of eggs enriched with n-3 PUFA over a period of three weeks had a positive effect on microvascular reactivity, on the lowering of blood pressure and triglycerides, so they concluded that omega-3 eggs could be efficient in preventing cardiovascular diseases. Laying hens have a limited ability to convert alpha-linolenic acid (ALA) into eicosapentaenoic acid (EPA) and docosahexaenoic acid (DHA) in their organism, and it is recommended that these fatty acids are taken in through feed, because in that way the enrichment of eggs with n-3 PUFA was more effective (Kralik 2007; Škrtić 2007, 2008). Oils (linseed, fish, rapeseed, soybean) are generally used as a source of energy from the laying hens' feed. Various studies have shown that the type of oil could have a significant impact on the profile of fatty acids in egg yolks (Rowghani et al. 2007; Aydin and Dogan 2010; Herkel et al. 2016). Fish oil is a rich source of essential n-3 PUFA, but if it is used in large amounts in feeding mixtures for poultry, then it has a negative effect on the organoleptic characteristics of meat and eggs (Scaife et al. 1994; Scheideler 1997). Rapeseed and linseed oils are well known sources of ALA that can convert to long chain n-3 polyunsaturated acids, such as EPA and DHA, through the elongation and desaturation processes (Yang et al. 2000).

Address for correspondence:

Gordana Kralik

Josip Juraj Strossmayer University of Osijek

Faculty of Agriculture in Osijek

Department of Special Zootechnics

V. Preloga 1, 31000 Osijek, Croatia

Phone: ++38531554863

E-mail: gkralik@pfos.hr

http://actavet.vfu.cz/ 
The aim of this research was to enrich eggs with n-3 PUFA, especially with EPA and DHA, by using a combination of linseed, rapeseed, soybean and fish oils in laying hens' diet at the amount of $5 \%$. Combination of different oils is interesting because of the interaction of individual fatty acids in the metabolic processes, as well as because of the impact on altering the n-6/n-3 PUFA ratio in yolk lipids. The control group of laying hens was given a diet containing $4.5 \%$ soybean oil and $0.5 \%$ fish oil. This paper aimed to investigate how and at what concentration the sources of ALA, EPA and DHA from oils, i.e. from feed, could influence their deposition in yolk lipids of table eggs. Furthermore, the intention was to determine the effects of the stated n-3 PUFA by consumption of $100 \mathrm{~g}$ of egg yolk, i.e. $100 \mathrm{~g}$ of egg mass of enriched eggs, and to compare them with conventional eggs.

\section{Materials and Methods}

The research was carried out on the Lohmann Classic laying hens aged 30-34 weeks. Laying hens were divided into two groups (control and experimental). Each group consisted of five cages, and each cage contained 40 hens (on the area of $750 \mathrm{~cm}^{2} /$ head), i.e. there were 200 hens in the $1^{\text {st }}$ group and 200 hens in the $2^{\text {nd }}$ group. Laying hens were fed diets of isoprotein and isocaloric composition during a period of four weeks (Table 1).

Apart from other feed ingredients, the $1^{\text {st }}$ group of hens was given diets containing $4.5 \%$ of soybean oil and $0.5 \%$ of fish oil (total $5 \%$ ), whereas the $2^{\text {nd }}$ group was fed diets composed of a combination of the following

Table 1. Composition of diets.

\begin{tabular}{lcc}
\hline Ingredients, $\%$ & $1^{\text {st }}$ group & $2^{\text {nd }}$ group \\
\hline Corn & 49.80 & 48.83 \\
Soybean cake & 26.13 & 25.62 \\
Sunflower cake & 3.91 & 5.00 \\
Dehydrated alfalfa & 2.00 & 2.00 \\
Livestock yeast & 0.50 & 0.50 \\
Limestone & 10.18 & 10.57 \\
Monocalcium phosphate & 1.51 & 1.51 \\
Salt & 0.32 & 0.32 \\
Methionine & 0.15 & 0.15 \\
Oil & $5.00^{1}$ & $5.00^{2}$ \\
Premix & 3.50 \\
Total & 0.50 & 0.50 \\
\hline Calculative values, $\%$ & 100.00 & 100.00 \\
\hline Crude protein & & \\
Crude fat & 18.0 & 18.0 \\
Crude fibres & 7.4 & 7.4 \\
Ash & 4.0 & 3.8 \\
\hline ME MJ/kg & 13.7 & 13.3 \\
\hline
\end{tabular}

${ }^{1}$ soybean oil $4.5 \%$, fish oil $0.5 \%$

${ }^{2}$ oil combination: linseed oil $1 \%$, fish oil $0.75 \%$, rapeseed oil $2 \%$, soybean oil $1.25 \%$

${ }^{3}$ Premix contains per $1 \mathrm{~kg}$ : vitamin A 200,000 UI, vitamin $\mathrm{D}_{3}$ 500,000 UI, vitamin $\mathrm{E} 10,000 \mathrm{mg}$, vitamin $\mathrm{K}_{3} 600 \mathrm{mg}$, vitamin $B_{1} 400 \mathrm{mg}$, vitamin $\mathrm{B}_{2} 1,000 \mathrm{mg}$, vitamin $\mathrm{B}_{6} 1,000 \mathrm{mg}$, vitamin $B_{12} 3,000 \mu \mathrm{g}$, vitamin $C 4,000 \mathrm{mg}$, vitamin $H 12 \mathrm{mg}$, vitamin $B_{3} 8,000 \mathrm{mg}$, vitamin $B_{5} 2,400 \mathrm{mg}$, vitamin $B_{9} 150 \mathrm{mg}$, vitamin $B_{4} 100,000 \mathrm{mg}$, iodine $200 \mathrm{mg}$, manganese $18,000 \mathrm{mg}$, zinc $14,000 \mathrm{mg}$, cobalt $30 \mathrm{mg}$, iron $12,000 \mathrm{mg}$, copper $1,600 \mathrm{mg}$, selenium inorganic $50 \mathrm{mg}$, calcium $238 \mathrm{~g}$, phytase 100,000 FYT, canthaxanthin $500 \mathrm{mg}$, beta-apo-beta carotene acid $300 \mathrm{mg}$, antioxidant (butylated hydroxytoluene) $20,000 \mathrm{mg}$ oils: linseed $1 \%$, fish $0.75 \%$, rapeseed $2 \%$, and soybean $1.25 \%$, which amounts to the same total of 5\%. Laying hens were administered feed and water ad libitum. During the experiment, the lighting regime was applied according to technological standards. Eggs used for the analysis were collected on the last day of the experiment. Two eggs were collected from each cage (total $n=10$ pcs)

The profile of fatty acids in egg yolk lipids was determined according to the method of Csapo et al. (1986) by using Chrompack CP-9000 gas chromatograph equipped with flame ionization detector. The operating conditions of the gas chromatography were as follows: $0.35 \mathrm{~g}$ of dried egg-yolk was weighed into a flask, $8 \mathrm{~cm}^{3}$ concentrated hydrochloric acid was added and it was boiled for $60 \mathrm{~min}$. After cooling down, $7 \mathrm{~cm}^{3}$ ethanol were added, then $15 \mathrm{~cm}^{3}$ diethylether following one min of shaking. The next extraction was with $15 \mathrm{~cm}^{3}$ benzine (b.p. $<60{ }^{\circ} \mathrm{C}$ ). After phase separation, the organic phase that contains about $150-200 \mathrm{mg}$ fat was separated and evaporated under vacuum on a rotadest. Then $4 \mathrm{~cm}^{3} 0.5 \mathrm{M}$ sodium-hydroxide in methanol was added, and boiled in a water bath for $5 \mathrm{~min}$. Next, $4 \mathrm{~cm}^{3} 14 \%$ boron-trifluoride in methanol were added and boiled for $3 \mathrm{~min}$ following the addition of $4 \mathrm{~cm}^{3} \mathrm{n}$-hexane. It was boiled for one min after which the level of the organic phase was brought to the neck of the flask with saturated sodium-chloride solution. When the phases were separated, samples were taken for analysis from the organic phase, and dried on sodium sulphate. The fatty acid methyl esters (FAMEs) were separated on a $100 \mathrm{~m} \times 0.25 \mathrm{~mm}$ wall coated open tubular (WCOT) column equipped with a CP-SIL 88 (FAME) stationary phase. The quantitation of FAMESs was obtained with a flame ionisation detector (FID) at $270{ }^{\circ} \mathrm{C}$. The temperature of the splitter injector was $270{ }^{\circ} \mathrm{C}$, the carrier gas was 
helium with the head pressure of $235 \mathrm{kPa}$. The oven was temperature programmed from $140{ }^{\circ} \mathrm{C}(10 \mathrm{~min})$ with $10{ }^{\circ} \mathrm{C} / \mathrm{min}$ increase up to $235^{\circ} \mathrm{C}(26 \mathrm{~min})$. The injected volume varied between 0.5 and $2 \mu 1$. The instrument was a Chrompack CP 9000 gas chromatograph (Chrompack, Delft, the Netherlands). Portions of saturated fatty acids (SFA) and monounsaturated fatty acids (MUFA), ALA, as well as EPA and DHA acids show as a percentage of total fatty acids contained in yolk lipids. The influence of different feeding treatments (oils) was determined by Student's $t$-test. Research results were processed by Statistica v. 8.0.

\section{Results}

Contents of fatty acids in linseed, fish, rapeseed and soybean oils ( $\%$ of total FA) are presented in Table 2.

Table 2. Profile of fatty acids in oils ( $\%$ of total fatty acids).

\begin{tabular}{|c|c|c|c|c|}
\hline Fatty acid & Linseed oil & Fish oil & Rapeseed oil & Soybean oil \\
\hline Myristic acid (C14:0) & 0.11 & 6.14 & 1.41 & 0.06 \\
\hline Pentadecanoic acid (C15:0) & 0.03 & 1.98 & 0.52 & 0.02 \\
\hline Palmitic acid (C16:0) & 6.81 & 21.92 & 7.66 & 4.70 \\
\hline Heptadecanoic acid (C17:0) & 0.16 & 1.31 & 0.32 & 0.04 \\
\hline Stearic acid (C18:0) & 3.83 & 5.90 & 2.82 & 2.34 \\
\hline Arachidic acid (C20:0) & 0.17 & 1.03 & 0.46 & 0.49 \\
\hline Behenic acid (C22:0) & 0.13 & 0.62 & 0.00 & 0.24 \\
\hline$\overline{\sum S F A *}$ & 11.23 & 38.90 & 13.20 & 7.89 \\
\hline Palmitoleic acid (C16:1) & 0.05 & 5.10 & 1.40 & 0.20 \\
\hline Heptadecenoic acid (C17:1) & 0.00 & 1.27 & 0.00 & 0.00 \\
\hline Oleic acid $(\mathrm{C} 18: \ln 9 \mathrm{c})$ & 18.78 & 17.34 & 42.86 & 63.89 \\
\hline Eicosenoic acid (C20:1n9) & 0.22 & 2.21 & 4.38 & 0.86 \\
\hline$\underline{\text { Erucic acid }(\mathrm{C} 22: \ln 9)}$ & 0.00 & 0.15 & 2.59 & 0.04 \\
\hline$\sum$ MUFA** & 19.04 & 26.07 & 51.23 & 64.82 \\
\hline Linoleic acid (C18:2n6) & 14.57 & 3.65 & 19.75 & 20.55 \\
\hline$\gamma$-linolenic acid (C18:3n6) & 0.12 & 0.48 & 0.49 & 0.00 \\
\hline Eicosadienoic acid (C20:2) & 0.06 & 0.68 & 0.43 & 0.03 \\
\hline Eicosatrienoic (C20:3n6) & 0.00 & 0.15 & 0.00 & 0.00 \\
\hline Arachidonic acid (C20:4n6) & 0.00 & 1.41 & 0.29 & 0.00 \\
\hline Docosadienoic acid (C22:2n6) & 0.00 & 0.63 & 0.00 & 0.08 \\
\hline$\sum \mathrm{n}-6$ PUFA*** & 14.75 & 7.00 & 20.96 & 20.66 \\
\hline$\alpha$-linolenic acid (C18:3n3) & 54.82 & 2.45 & 14.48 & 6.63 \\
\hline Eicosatrienoic acid (C20:3n3) & 0.15 & 0.10 & 0.13 & 0.00 \\
\hline Eicosapentaenoic acid (C20:5n3) & 0.00 & 7.15 & 0.00 & 0.00 \\
\hline Docosahexaenoic acid (C22:6n3) & 0.00 & 18.34 & 0.00 & 0.00 \\
\hline$\overline{\sum n-3}$ PUFA & 54.97 & 28.04 & 14.61 & 6.63 \\
\hline$\sum$ n-6 PUFA $/ \sum$ n-3 PUFA & 0.27 & 0.25 & 1.43 & 3.12 \\
\hline
\end{tabular}

*SFA - saturated fatty acids; **MUFA - monounsaturated fatty acids; ***PUFA - polyunsaturated fatty acids

Linseed oil contains $54.82 \%$ ALA. Rapeseed oil and soybean oil contain the most monounsaturated fatty acids $(51.23 \%$ and $64.82 \%$, respectively), of which oleic acid (OA, 42.86\% and 63.89\%, respectively) is the most represented. Rapeseed and soybean oils also contain linoleic acid (LA, $19.75 \%$ and $20.55 \%$, respectively), and ALA (14.48\% and $6.63 \%$, respectively). Fish oil is rich in saturated fatty acids (SFA, 38.90\%), and EPA $(7.15 \%)$ and DHA (18.34\%) are represented from the n-3 PUFA group. 
The $n-6 / n-3$ PUFA ratio in oils is very narrow, ranging from 0.27 (for linseed oil) to 3.12 (for soybean oil). Fatty acid profile in laying hens' feed depends on the type and concentration of supplemented oils (Table 3).

Table 3. Profile of fatty acids in laying hens' diet (\% of total fatty acids).

\begin{tabular}{lrc}
\hline Fatty acid & $1^{\text {st }}$ group & $2^{\text {nd }}$ group \\
\hline Myristic acid (C14:0) & 2.27 & 1.69 \\
Pentadecanoic acid (C15:0) & 0.09 & 0.25 \\
Palmitic acid (C16:0) & 13.07 & 12.73 \\
Heptadecanoic acid (C17:0) & 0.12 & 0.13 \\
Stearic acid (C18:0) & 3.29 & 3.19 \\
Arachidic acid (C20:0) & 0.55 & 0.41 \\
Behenic acid (C22:0) & 0.79 & 0.70 \\
Lignoceric acid (C24:0) & 0.26 & 0.17 \\
\hline SFA* & 20.43 & 19.27 \\
\hline Palmitoleic acid (C16:1) & 0.20 & 0.51 \\
Oleic acid (C18:1n9c) & 33.02 & 24.97 \\
Eicosenoic acid (C20:1n9) & 0.40 & 0.51 \\
Erucic acid (C22:1n9) & 0.04 & 0.06 \\
\hline$\sum$ MUFA** & 33.66 & 26.05 \\
Linoleic acid (C18:2n6) & 41.49 & 35.98 \\
$\gamma$-linolenic acid (C18:3n6) & 0.29 & 0.32 \\
Eicosadienoic acid (C20:2) & 0.29 & 0.30 \\
Eicosatrienoic (C20:3n6) & 0.10 & 0.13 \\
Arachidonic acid (C20:4n6) & 0.14 & 0.07 \\
Docosadienoic acid (C22:2n6) & 0.26 & 0.48 \\
\hline$\sum$ n-6 PUFA*** & 42.57 & 37.28 \\
\hline$\alpha$-linolenic acid (C18:3n3) & 3.12 & 13.36 \\
Eicosatrienoic acid (C20:3n3) & 0.09 & 0.15 \\
Eicosapentaenoic acid (C20:5n3) & 0.09 & 1.16 \\
Docosahexaenoic acid (C22:6n3) & 0.04 & 2.74 \\
\hline$\sum$ n-3 PUFA & 3.34 & 2.14 \\
$\sum$ n-6 PUFA/ n-3 PUFA & 12.75 & \\
\hline & &
\end{tabular}

*SFA - saturated fatty acids; **MUFA - monounsaturated fatty acids; ***PUFA - polyunsaturated fatty acids

The greatest difference between laying hens' diets was noticed in the content of n-6 PUFA and n-3 PUFA. The $1^{\text {st }}$ group being fed diet supplemented with $4.5 \%$ soybean oil and $0.5 \%$ fish oil contained $42.57 \%$ of n- 6 PUFA and only $3.34 \%$ of n-3 PUFA, so the ratio of n-6/n-3 PUFA was 12.75 . Diet given to the $2^{\text {nd }}$ group contained $37.28 \%$ of $n-6$ PUFA and $17.40 \%$ of n-3 PUFA and their ratio was 2.14 . The most represented fatty acid in n-6 PUFA group in both laying hens' diets was LA (41.49\% and $35.98 \%$, respectively). In total n-3 PUFA, ALA was present at important amounts in both diets $(3.12 \%$ and $13.36 \%$, respectively). It should be pointed out that the content of DHA in the diet of the $1^{\text {st }}$ group was $\times 68.5$ higher than in the diet given to the $2^{\text {nd }}$ group.

Table 4 overviews the profile of fatty acids ( $\%$ of total FA) in yolk lipids of the $1^{\text {st }}$ and $2^{\text {nd }}$ group. In yolk lipids, eggs laid by the $2^{\text {nd }}$ group contained significantly less $\sum$ SFA than the $1^{\text {st }}$ group $(31.33 \%: 34.72 \%, P<0.001)$. Similar results were obtained 
Table 4. Fatty acid profile in lipids of egg yolk ( $\%$ of total fatty acids, $n=10)$.

\begin{tabular}{|c|c|c|c|}
\hline Fatty acid & $1^{\text {st }}$ group $\bar{x} \pm$ sd & $2^{\text {nd }}$ group $\bar{x} \pm$ sd & $P$-value \\
\hline Myristic acid (C14:0) & $0.34^{\mathrm{a}} \pm 0.03$ & $0.29^{b} \pm 0.03$ & 0.005 \\
\hline Pentadecanoic acid (C15:0) & $0.20 \pm 0.03$ & $0.19 \pm 0.04$ & 0.688 \\
\hline Palmitic acid (C16:0) & $22.16^{\mathrm{a}} \pm 1.13$ & $19.86^{b} \pm 1.58$ & 0.001 \\
\hline Heptadecanoic acid (C17:0) & $0.34 \pm 0.07$ & $0.34 \pm 0.04$ & 0.759 \\
\hline Stearic acid (C18:0) & $8.29 \pm 1.13$ & $7.69 \pm 1.20$ & 0.265 \\
\hline Arachidic acid (C20:0) & $0.17 \pm 0.04$ & $0.17 \pm 0.02$ & 0.928 \\
\hline Heneicosanoic acid (C21:0) & $0.12 \pm 0.02$ & $0.13 \pm 0.02$ & 0.426 \\
\hline Tricosanoic acid (C23:0) & $3.00 \pm 0.36$ & $2.66 \pm 0.61$ & 0.144 \\
\hline$\overline{\sum \mathrm{SFA}^{*}}$ & $34.72^{a} \pm 1.13$ & $31.33^{\mathrm{b}} \pm 0.64$ & $<0.001$ \\
\hline Myristoleic acid (C14:1) & $0.17 \pm 0.04$ & $0.17 \pm 0.03$ & 0.705 \\
\hline Palmitoleic acid (C16:1) & $2.43^{\mathrm{a}} \pm 0.35$ & $2.00^{\mathrm{b}} \pm 0.30$ & 0.008 \\
\hline Elaidic acid (C18:1n9t) & $0.02 \pm 0.004$ & $0.02 \pm 0.002$ & 0.151 \\
\hline Oleic acid $(\mathrm{C} 18: \ln 9 \mathrm{c})$ & $38.67 \pm 1.93$ & $38.94 \pm 1.28$ & 0.725 \\
\hline Eicosenoic acid (C20:1n9) & $0.22^{b} \pm 0.04$ & $0.27^{\mathrm{a}} \pm 0.03$ & 0.002 \\
\hline Erucic acid $(\mathrm{C} 22: 1 \mathrm{n} 9)$ & $0.31^{\mathrm{b}} \pm 0.04$ & $0.37^{\mathrm{a}} \pm 0.05$ & 0.013 \\
\hline$\sum \mathrm{MUFA}^{* *}$ & $41.82 \pm 2.04$ & $41.76 \pm 1.08$ & 0.939 \\
\hline Linoleic acid (C18:2n6) & $19.13 \pm 1.87$ & $17.83 \pm 0.8$ & 0.060 \\
\hline$\gamma$-linolenic acid (C18:3n6) & $0.24 \pm 0.03$ & $0.22 \pm 0.03$ & 0.085 \\
\hline Eicosadienoic acid (C20:2n6) & $0.26 \pm 0.08$ & $0.32 \pm 0.08$ & 0.158 \\
\hline Eicosatrienoic acid (C20:3n6) & $0.36 \pm 0.05$ & $0.35 \pm 0.05$ & 0.641 \\
\hline Arachidonic acid (C20:4n6) & $0.57 \pm 0.07$ & $0.61 \pm 0.05$ & 0.128 \\
\hline Docosadienoic acid (C22:2n6) & $0.28 \pm 0.043$ & $0.26 \pm 0.02$ & 0.085 \\
\hline$\sum \mathrm{n}-6 \mathrm{PUFA} * * *$ & $20.85 \pm 1.91$ & $19.59 \pm 0.83$ & 0.071 \\
\hline$\alpha$-linolenic acid (C18:3n3) & $1.17^{\mathrm{b}} \pm 0.15$ & $4.73^{\mathrm{a}} \pm 0.21$ & $<0.001$ \\
\hline Eicosatrienoic (C20:3n3) & $0.02 \pm 0.01$ & $0.03 \pm 0.01$ & 0.115 \\
\hline Eicosapentaenoic acid (C20:5n3) & $0.06^{\mathrm{b}} \pm 0.02$ & $0.20^{\mathrm{a}} \pm 0.03$ & $<0.001$ \\
\hline Docosahexaenoic acid (C22:6n3) & $1.35^{\mathrm{b}} \pm 0.22$ & $2.37^{\mathrm{a}} \pm 0.18$ & $<0.001$ \\
\hline$\overline{\sum n-3}$ PUFA & $2.60^{\mathrm{b}} \pm 0.18$ & $7.32^{\mathrm{a}} \pm 0.23$ & $<0.001$ \\
\hline$\sum \mathrm{n}-6 / \sum \mathrm{n}-3$ PUFA & $8.02^{\mathrm{a}} \pm 0.64$ & $2.68^{b} \pm 0.12$ & $<0.001$ \\
\hline
\end{tabular}

$\bar{x}=$ arithmetic means; $\mathbf{s d}=$ standard deviation; ${ }^{\mathrm{a}, \mathrm{b}} P<0.05, P<0.01$ or $P<0.001$

*SFA - saturated fatty acids; **MUFA - monounsaturated fatty acids; ***PUFA - polyunsaturated fatty acids

Table 5. Concentration of n-3 PUFA in yolks and in eggs.

\begin{tabular}{lcccc}
\hline \multirow{2}{*}{$\begin{array}{l}\text { Fatty } \\
\text { Acid }\end{array}$} & \multicolumn{2}{c}{$1^{\text {st }}$ group } & \multicolumn{2}{c}{$2^{\text {nd }}$ group } \\
\cline { 2 - 5 } & $\mathrm{mg} / 100 \mathrm{~g}$ of yolk & $\mathrm{mg} / 100 \mathrm{~g}$ of egg & $\mathrm{mg} / 100 \mathrm{~g}$ of yolk & $\mathrm{mg} / 100 \mathrm{~g}$ of egg \\
\hline ALA* & 254.2 & 108.0 & 1102.0 & 435.0 \\
EPA** & 14.10 & 5.99 & 46.63 & 18.43 \\
DHA** & 291.7 & 124.0 & 552.1 & 218.2 \\
\hline
\end{tabular}

*ALA - $\alpha$-linolenic acid; **EPA - eicosapentaenoic acid; *** DHA - docosahexaenoic acid 
by Kralik et al. (2008) in their previous research of use of fish oil in production of table eggs. Eggs produced in the $2^{\text {nd }}$ group contained significantly $(P<0.05)$ less palmitoleic acid, and more eicosenoic acid. Differences in total contents of MUFA and n-6 PUFA between eggs of both groups were not significant $(P>0.05)$.

Table 5 presents concentrations of ALA, EPA and DHA in egg yolks and in total egg mass of the $1^{\text {st }}$ and $2^{\text {nd }}$ group.

The content of ALA was $254.2 \mathrm{mg} / 100 \mathrm{~g}$ in egg yolks of the $1^{\text {st }}$ group, and $1102 \mathrm{mg} / 100 \mathrm{~g}$ of the $2^{\text {nd }}$ group. The content of EPA was increased from $14.1 \mathrm{mg} / 100 \mathrm{~g}$ to $46.63 \mathrm{mg} / 100 \mathrm{~g}$. The content of DHA was also increased from 291.7 to $552.1 \mathrm{mg} / 100 \mathrm{~g}$ of yolk. In comparison to the content of FA in whole eggs of the $1^{\text {st }}$ group, eggs of the $2^{\text {nd }}$ group had ALA increased by $\times 4.02$, EPA by $\times 3.07$, and DHA by $\times 1.75$.

\section{Discussion}

Our research results regarding the content of n-3 PUFA in oils proved that there were some differences. Linseed oil is rich in ALA (54.85\%), fish oil is rich in DHA (18.34\%) and EPA $(7.15 \%)$. Rapeseed oil and soybean oil contain great amounts of oleic acid $(42.86 \%$ and $63.89 \%$, respectively). As of the n-3 PUFA group, ALA is the only one present in both types of oil. These results are in accordance with those published by Rowghani et al. (2007), Kralik et al. (2008), Antongiovanni et al. (2009) and Salamatdoustnobar et al. (2009), although there is very little fluctuation referring to FA, caused by the origin of oil. In general, plant oils contain less than $25 \%$ ALA, with the exception of linseed oil, which is rich in ALA (Hiltunen and Holm 2000; Herkel et al. 2016). ALA in linseed oil varies between 34.1 and $64.4 \%$ (Hiltunen and Holm 2000). The time of harvest and plant processing affects the yield and quality of linseed oil (Nykter and Kymäläinen 2006). The n- 6 PUFA/n-3 PUFA ratio in linseed oil is $4: 1$. The diet fed to the $2^{\text {nd }}$ group contained more MUFA than the diet of the $1^{\text {st }}$ group (33.66\%: $26.05 \%$, respectively), but the most common one was oleic acid (33.02\%:24.07\%, respectively). The diet for the $1^{\text {st }}$ group was richer in linoleic acid than the diet composed for the $2^{\text {nd }}$ group (41.49\%:35.98\%). At the same time, the $2^{\text {nd }}$ group was given a diet containing more ALA, EPA and DHA than the $1^{\text {st }}$ group (13:36\%, $1.16 \%$ and $2.74 \%$ compared to $3.12 \%, 0.09 \%$ and $0.04 \%$, respectively).

We did not establish significant differences in LA between groups of eggs, although eggs from the $2^{\text {nd }}$ group contained less LA, but slightly more arachidonic acid $(P>0.05)$, which is the opposite to our previous research results (Kralik et al. 2008), as well as to research results of Sari et al. (2002) and Husveth et al. (2003). Beynen (2004) determined that only high concentration of LNA in a diet affected the synthesis of detectable content of EPA in yolks, which was generally lower than the content of DHA. The author also stated that LA from feed incorporated more efficiently into the yolk than ALA.

Eggs from hens of the $2^{\text {nd }}$ group contained more n-3 PUFA than the $1^{\text {st }}$ group $(P<$ $0.001)$. When compared to the $1^{\text {st }}$ group, higher portions of ALA $(4.73 \%: 1.17 \%)$, EPA $(0.20 \%: 0.06 \%)$, DHA $(2.37 \%: 1.35 \%)$ and $n-3$ PUFA $(7.32 \%: 2.60 \%)$ were determined in the yolk lipids of the $2^{\text {nd }}$ group. Although the diet given to the $1^{\text {st }}$ group of hens contained smaller amounts of EPA and DHA, these fatty acids were detected in yolk lipids, because laying hens can synthesize EPA and DHA at a limited amount if the diet contains ALA at a sufficient amount (Kralik et al. 2008). Increased amounts of EPA and DHA in feed resulted in increased deposition of DHA in the yolks lipids of the $2^{\text {nd }}$ group, which is a result of dietary supplementation with different oils. Similar results were achieved by Bavelaar and Beynen (2004) and Huyghebaert et al. (2007). Kralik et al. (2008) reported that dietary supplementation of laying hens' feed with various combinations of fish and rapeseed oils, instead of soybean oil, resulted in the increased content of n-3 PUFA for $\times 1.4$ to 2.10 . 
Rowghani et al. (2007) stated that rapeseed oil (3\% and 5\%) increased the percentage of ALA to $3.43 \%$ and $6.02 \%$, respectively, and also affected the increase of DHA. Linseed oil also increased $\Sigma$ n-3 PUFA to $4.72 \%$ and $6.80 \%$ when compared to the control $(1.43 \%)$, which was also found by Herkel et al. (2016). Lewis et al. (2000) determined that supplementation of $7 \%$ rapeseed oil affected the increase of ALA by $\times 1.2 \%$ to $6.3 \%$, and the increase of DHA $\times 4$. The authors concluded that three eggs enriched with $n-3$ PUFA correspond to the amount of n-3 PUFA in one fish meal daily. Bearing in mind that people are more prone to consume eggs than fish, they can thus be an alternative source of n-3 PUFA. According to the Canadian standards, it is recommended to consume eggs enriched with n-3 PUFA by up to 50\% of energy in a meal. Samman et al. (2009) stated that omega eggs had significantly lower percentage of myristic and palmitic acids, which resulted in a lower percentage of SFA, but significantly higher percentage of ALA, DHA and total omega-3, which is also the case in our research. Gül et al. (2012) pointed out that dietary supplementation of laying hens' feed with rapeseed oil resulted in increased MUFA, especially of oleic acid, in eggs. In this research, oleic acid in egg yolk was at approximately the same level in both groups $(>45 \%)$.

The ratio of n-6/n-3 PUFA in yolk lipids was 2.68 in the $2^{\text {nd }}$ group, and 8.02 in the $1^{\text {st }}$ group $(P<0.001)$. Sugano (1996) stated that the optimal ratio of $n-6 / n-3$ PUFA in human nutrition was $3: 1$, however, some studies in developed industrial countries proved this ratio to range from 10:1 and to $15: 1$ and more (Simopoulos 2000). Our research proved that the feeding treatment in the $2^{\text {nd }}$ group (combination of plant and fish oils) was very efficient in enriching yolk lipids with n-3 PUFA, and consequently in reducing the n-6/n-3 PUFA ratio, compared to the feeding treatment with soybean oil and fish oil.

In line with Meluzzi et al. (2000), Kralik et al. (2008) and Herkel et al. (2016), enrichment of eggs with the n-3 PUFA depended on the increased content of n-3 PUFA in the hens' diet, and it was connected with the lowering of n-6 PUFA in egg yolks. According to Simopoulos (2000), LA and ALA are very important as precursors of n-6 PUFA and n-3 PUFA. Linoleic acid is metabolized into other n-6 fatty acids, including AA. Alphalinolenic acid is metabolized into the n-3 fatty acids, such as EPA and DHA. When LA is present at larger amounts, it will inhibit the transformation of ALA into EPA and DHA, and with insufficient amount of LA, lower AA concentration will be created, which was not the case in our research. Our results show that the narrowing of the $n-6 / n-3$ PUFA ratio and the increase of the n-3 PUFA content in feed can affect the FA profile in yolk lipids directed towards the increased deposition of n-3 PUFA, which was also reported by Beynen (2004), Škrtić et al. (2007), as well as by Kralik et al. (2008). Bavelaar and Beynen (2004) proved a linear relationship between ALA and LA in feed and their contents in yolk lipids.

The recommended daily intake of n-3 PUFA is $0.5 \%$ of the total energy in a meal (Anon 1990), which is an equivalent to 1.1-1.5 g FA for adults. Ferrier et al. (1995) calculated that feeding laying hens with diets containing $10 \%$ linseed oil, which is rich in ALA, results in production of eggs, where only one egg covers $30 \%$ of the n-3 PUFA daily requirements. Such egg contains $264 \mathrm{mg}$ ALA, $10 \mathrm{mg}$ EPA and $82 \mathrm{mg}$ DHA. Jiang et al. (1991) also reported that EPA and DHA could be increased in yolk lipids when the feed was rich in ALA that was converted to EPA and DHA in the laying hens' livers, and synthesized fatty acids were deposited in the egg yolks. That conversion may be inhibited by high LA concentration. Beynen (2004) determined that higher amounts of linseed in feed affected the increased deposition of EPA and DHA in yolk lipids, whereas the feeding of hens with soybean was less efficient. The author concluded that the diet enriched with linseed or soybean influenced the deposition of $141 \mathrm{mg}$ and $98 \mathrm{mg}$ of DHA, unlike in the control group, where egg yolks contained $78 \mathrm{mg}$ of DHA. Favorable effects on human health can be achieved by daily consumption of $0.5 \mathrm{~g}$ of $\mathrm{n}-3$ PUFA (Mantzioris 2000). The results 
of this research proved that $100 \mathrm{~g}$ of egg mass from the $2^{\text {nd }}$ group contained $435 \mathrm{mg}$ ALA, $18.43 \mathrm{mg}$ EPA and $218.2 \mathrm{mg}$ DHA, which is significantly more than in the $1^{\text {st }}$ group, and also more than reported by the mentioned authors.

Modified diets administered to laying hens influenced the deposition of fatty acids in eggs. The EPA content was increased from 0.06 to $0.20 \%$; the DHA content from 1.35 to $2.37 \%(P<0.001)$. Compared to the $1^{\text {st }}$ group, total n-3 PUFA were increased from 2.60 to $7.32 \%$ in total fatty acids in egg yolks of the $2^{\text {nd }}$ group. Eggs laid in the $2^{\text {nd }}$ group of hens contained 435 ALA, 18.4 EPA, and 218.2 DHA mg/100 g of eggs, which marked an increase of $\times 4$ for ALA, $\times 3$ for EPA, and $\times 1.7$ for DHA in comparison to the $1^{\text {st }}$ group. Furthermore, the total n-3 PUFA was increased in the $2^{\text {nd }}$ group $\times 2.8$ compared to the $1^{\text {st }}$ group. This leads to the conclusion that consumption of eggs enriched with n-3 PUFA can have an important beneficial effect on human health.

\section{Acknowledgement}

This paper is a part of the research unit "Research, Production and Medical Testing of Functional Food" within "The Scientific Centre of Excellence for Personalized Health Care" financed by the Ministry of Science, Education and Sports of the Republic of Croatia.

\section{References}

Anonymous 1990. Nutrition Recommendations. Health and Welfare. Ministry of Supply and Services, Ottawa

Antongiovanni MS, Minieri A, Buccioni I, Galligani I, Rapaccini S. 2009: Transfer of dietary fatty acid from butyric acid fortified canola oil into the meat of broiler. Ital J Anim Sci 8: 754-756

Aydin R, Dogan I 2010: Fatty acid profile and cholesterol content of egg yolk from chickens fed diets supplemented with purlslane (Portulaca olarecae L.). J Sci Food Agric 90: 1759-1763

Bavelaar FJ, Beynen AC 2004: Relationships between the intake of n-3 polyunsaturated fatty acids by hens and the fatty acid composition of their eggs. Int J Poult Sci 3: 690-696

Beynen AC 2004: Fatty acid composition of eggs produced by hens fed diets containing groundnut, soya bean or linseed. NJAS - Wagen J Life Sc 52: 3-10

Csapó J, Sugár L, Horn A, Csapó Jne 1986: Chemical composition of milk from red deer, roe and fallow deer kept in captivity. Acta Agron Hung 36: 359-372

Ferrier LK, Caston LJ, Leeseon S, Squires J, Weaver BJ, Holub BJ 1995: Alpha-linolenic acid and docosahexaenoic acid enriched eggs from hens fed flaxseed: influence on blood lipids and platelet phospholipid fatty acids in humans. Am J Clin Nutr 62: 81-86

Gül M, Yoruk MA, Aksu T, Kaya A, Kaynar O 2012: The effect of different levels of canola oil on performance, egg shell quality and fatty acid composition of laying hens. International Journal of Poultry Sciences 11: 769-776

Hiltunen R, Holm Y 2000: Lipid. In: Hiltunen R \& Holm Y (Eds): Farmakognosia. Yliopistopaino, Helsinki, pp $142-170$

He X, Yang X, Guo Y 2007: Effects of different dietary oil sources on immune function in cyclophosphamide immunosuppressed chickens. Anim Feed Sci Technol 139: 186-200

Herkel R, Gálik R, Arpášova H, Bíro D, Juráček M, Šimko M, Rolinec M 2016: Fatty acid profile and nutritional composition of table eggs after supplementation by pumpkin and flaxseed oils. Acta Vet Brno 85: 277-283

Husveth F, Rozsa L, Magyar L, Bali G, Papocsi P 2003: N-3 fatty acid enrichment of table eggs by adding a fish oil preparation (Nordos Fat ${ }^{\mathrm{R}}$ ) to the diet of laying hens. Arch Geflugelkd 67: 198-203

Huyghebaert G, Raes K, Maertens L, Arnouts S, Delezie E. 2007: The interactive impact of dietary PUFA on the deposition of DHA in the egg yolk. In: Proceedings of the $16^{\text {th }}$ European Symposium on Poultry Nutrition, in August in Strasbourg, France, pp 681-684

Jiang Z, Ahn DU, Sim J 1991: Effect of feeding flax and two types of sunflower seeds on fatty acid compositions of yolk lipid classes. Poult Sci 41: 2467-2475

Kralik G, Škrtić Z, Gajčević Z, Hanžek D 2007: Effect of different oils supplemented to laying hens〉 diets on the quality of eggs and the fatty acid content in egg yolk (In Croatian). Krmiva 49: 115-125

Kralik G, Gajčević Z, Škrtić Z 2008: The effect of different oil supplementations on laying performance and fatty acid composition of egg yolk. Ital J Anim Sci 7: 173-183

Lewis NM, Seburg S, Flanagan NL 2000: Enriched eggs a source of fatty acids for humans. Poult Sci 79: 971-974

Mantzioris E 2000: Biochemical effects of a diet containing food enriched with n-3 fatty acids. Am J Clin Nutr 72: $42-48$

Meluzzi A, Sirri F, Manfreda G, Tallarico N, Franchini A 2000: Effect of dietary vitamin E on the quality of table eggs enriched with n-3 long chain fatty acids. Poult Sci 79: 539-545 
Nykter M, Kymäläinen HR 2006: Quality characteristics of edible linseed oil. Agri Food Sci 15: 402-413

Okuyama H, Kobayashi T, Watanabe S, 1997: Dietary fatty acids - the n-6/n-3 balance and chronic elderly disease. Excess linolenic acid and relative n-3 deficiency syndrome seen in Japan. Prog Lipid Res 35: 409-457

Pita MCG, Piber Neto E, Carvalho PR, Mendonca Junior CX 2010: Efrito da suplemnentacao, oleo de canola e vitamina E na dieta dobre as concentracoes de acidos graxos poliinsaturados em ovos de galinha. Arq Bras Med Vet Zootec 59: 789-796

Raes K, Huyghebaert G, De Smet S, Nollet L, Arnouts S, Demeyer D 2002: The deposition on conjugated linolenic acids in eggs of laying hens fed diets varying in fat level and fatty acid profile. J Nutr 132: 182-189

Rašić L, Čavka A, Kralik Z, Kralik G, Šerić V, Drenjančević I. 2014: Effect of omega-3 ennriched food on blood pressure microcirculation and lipid profile in young healthy men. In: Abstract Book of the Third International Symposium on Hypertension ISHOP3, in November in Osijek, Croatia, p. 13

Rowghani E, Arab M, Nazifi S, Bakhtiari Z 2007: Effect of canola oil on cholesterol and fatty acid composition of egg-yolk of laying hens. International Journal of Poultry Science 6: 111-114

Salamatdoustnobar R, Nazeradi K, Ayazi A, Hamidiyan A, Gorbani A, Fani, A 2009: Benefical effects of canola oil on serum biochemical parameters of Iranian native turkeys. J Anim Vet Adv 8: 2206-2209

Samman S, Kung FP, Carter LM, Foster MJ, Ahmad ZI, Phuyal JL, Petocz P 2009: Fatty acid composition of certified organic, conventional and omega-3 eggs. Food Chem 116: 911-914

Sari M, Aksit M, Özdogan M, Bamacioglu H, 2002: Effects of addition of flaxseed to diets of laying hens on some production characteristics, levels of yolk and serum cholesterol, and fatty acid composition of yolk. Arch Geflugelkd 66: 75-79

Scaife RJ, Moyo J, Galbraith H, Michie W, Campbell V 1994: Effect of dietary supplemental fats and oils on the tissue fatty acid composition and growth of female broilers. Brit Poultry Sci 35: 107-118

Scheideler SE 1997: Studies of consumer acceptance of high omega-3 fatty acid-enriched eggs. J Appl Poultry Res 6:137-146

Simopoulos AP 2000: Human requirement for n-3 polyunsaturated fatty acids. Poultry Sci 79: 961-970

StatSoft, Inc. 2012. STATISTICA (data analysis software system), version 8.0. www.statsoft.com

Sugano M 1996: Characteristics of fats in Japanese diets and current recommendations. Lipids 31: 283-286

Škrtić Z, Kralik G, Gajčević Z, Bogut I, Hanžek D 2007: The increase of the n-3 PUFA content in eggs. Poljoprivreda 13: 47-52

Škrtić Z, Kralik G, Gajčević Z, Hanžek D 2008: Effect of different source of oils on fatty acid profile and organoleptic traits of eggs. Acta Agric Slov 92: 213-217

Van Elswik ME 1997: Comparison of n-3 fatty acids sources in laying hen rations for improvement of whole egg nutritional quality. Brit J Nutr 78: S61-S69

Yang CX, Ji C, Ding LM, Rong Y 2000: N-3 fatty acid metabolism and effects of alpha-linolenic acid on enriching n-3 FA eggs. J Chi Agri Uni 95: 117-122 